\title{
Pengaruh Bahan Pengisi Cangkang Kelapa Sawit Komposit-Silicone Rubber Dalam Permulaan Pemohonan Listrik
}

\author{
Fitriah $^{1 *)}$, Rudi Kurnianto ${ }^{2)}$, and Managam Rajagukguk ${ }^{3)}$ \\ 1,2,3) Department of Electrical Engineering, Tanjungpura University, Indonesia \\ Corresponding Email: ${ }^{*}$ fitriah@ee.untan.ac.id
}

\begin{abstract}
Inception of electrical treeing can irreversibly deteriorate the insulation of polymeric power cables leading to a complete failure and initial process of degradation in polymer insulation due to a void that experiences high electric field stress in the material. This paper present will study filler's influence on inception of electrical treeing growth in silicone rubber - oil palm endokaprium composite. The observed data is inception voltage and time phenomena in two types of test sample, that is " with filler " and " without filler ". Sample of filler consisted of silicone rubber and oil palm endokaprium composite for oil palm endokaprium weight is 0.1 grams and weight silicone rubber 3.9 gram. While the sample without filler is only silicone rubber. It is obtained that the tree inception voltages dan time for "with" dan "without filler" specimens are $8 \mathrm{kV} / 182$ seconds and 7,5 kV / 137 seconds, respectivelly.. It is considered that "filler" acted as a barrier for tree inception. We throught that "filler" enhanced dielectric strength of silicone rubber and oil palm endokaprium by disturbing high electric field stress, result in higher tree inception voltage and longer tree inception time.
\end{abstract}

Key words : Insulation, Silicone Rubber, Oil Palm Endokaprium, Electrical treeing.

\section{Pendahuluan}

Isolasi adalah salah satu faktor penting dalam mendesain sebuah kabel. Banyak jenis bahan isolasi yang telah digunakan salah satunya Polyvinyl Chloride (PVC) dan Low Density Polyethylene (LDPE). Kabel isolasi polimer mempunyai banyak kelebihan dibandingkan dengan kabel Oil Filled (OF). Ketahanannya yang tinggi terhadap penuaan termal (thermal aging) membuat kabel polimer lebih efisien daripada kabel Oil Filled (OF)[1].

Titik kritis yang berpengaruh pada unjuk kerja kabel polimer adalah adanya cacat. Cacat itu dapat timbul dalam bentuk celah (void), ketidakmurnian (impurity) dan tonjolan pada permukaan (interface) antara lapisan semikonduktor dan isolasi polimer [2].

Akibat adanya stress listrik dan stress termal yang terus menerus maka akan terjadi penuaan isolasi polimer dan pada cacat ini tumbuh pemohonan listrik (electrical treeing). Dengan kata lain permulaan pemohonan listrik merupakan proses awal degradasi dalam isolasi polimer karena adanya rongga (void) yang mengalami stress medan listrik tinggi di dalam material [3].

Dua penuaan yang paling sering dialami pada kabel berisolasi polimer adalah void discharge dan electrical treeing [4].
Selain disebabkan oleh void dan material konduktif, tembus peluahan bergantung juga pada berbagai macam parameter, seperti konfigurasi elektroda, ketebalan dielektrik, temperatur, tekanan, sifat dan morfologi dari material [5], [6].

Material silicone rubber memiliki kelebihan dibanding dengan jenis keramik dan kaca karena silicone rubber tahan terhadap cuaca, bebannya ringan, dan dapat mempertahankan sifat hidrofobiknya untuk waktu yang lama. Material silicone rubber juga memiliki kemampuan untuk memulihkan sifat hidrofobiknya [7], [8].

Kelapa sawit merupakan salah satu komoditas andalan Indonesia yang perkembangannya sangat pesat. Dalam industri pengolahan minyak sawit atau Crude Palm Oil (CPO) akan diperoleh limbah industri. Limbah ini digolongkan menjadi limbah padat, cair, dan gas. Salah satu jenis limbah padatnya yaitu cangkang kelapa sawit. Cangkang kelapa sawit merupakan salah satu limbah yang jumlahnya mencapai $60 \%$ dari produksi minyak inti. Limbah cangkang kelapa sawit berwarna hitam keabuan, bentuk tidak beraturan, dan memiliki kekerasan cukup tinggi. Cangkang sawit mengandung selulosa sebesar $45 \%$ dan hemiselulosa sebesar 26\% [8].

Mengikuti perkembangannya, isolasi polimer komposit dengan bahan pengisi (filler) mineral semakin populer, karena mudah dalam desain dan pembuatannya. Sejalan dengan perkembangan teknologi dewasa ini menuntut kita untuk terus mencari dan meneliti bahan isolasi yang murah tetapi mempunyai kekuatan listrik, mekanik dan termal yang tinggi [7], [9]. Untuk itu dalam penelitian ini dibuat sebagai bahan pengisi (filler) dari serbuk cangkang kelapa sawit dikombinasikan dengan silicone rubber.

Pada penelitian ini dibuatlah bahan isolasi komposit silicone rubber dan cangkang kelapa sawit. Penggunaan cangkang kelapa sawit yang merupakan serat alam dengan kombinasi campuran yang sesuai pada matriks akan menghasilkan komposit yang lebih baik [10]. Penelitian sebelumnya dinyatakan bahwa cangkang kelapa sawit bersifat penghalang (barrier) dan penetral muatan, tetapi karena bahan serat alami mempunyai kelemahan mudah menyerap air untuk itu penelitian ini mencampurkan dengan silicone rubber karena bahan isolasinya telah terbukti mempunyai sifat hidrofobik atau tahan air dan dapat memulihkan diri (self-healing)[11]. Dengan demikian di harapkan kedua bahan tersebut jika di buat bahan isolasi komposit akan lebih baik untuk menghalangi terjadinya pemohonan listrik.

Permasalahan dalam penelitian ini adalah bagaimana 
pengaruh filler silicone rubber - cangkang kelapa Sawit dalam permulaan pemohonan listrik (electrical treeing). Adapun tujuan yang akan dicapai dalam penelitian ini adalah untuk mengetahui pengaruh bahan pengisi (filler) terhadap tegangan insepsi (inception voltage) dan waktu insepsi (inception time) pemohonan listrik (electrical treeing) dengan sampel bahan isolasi silicone rubber dan cangkang kelapa sawit komposit.

\section{Metodologi}

Pemohonan listrik tumbuh di daerah yang mengalami stress medan listrik tinggi, seperti pada ketajaman metalik (metallic asperities), dimana tempat-tempat yang mengandung kontaminasi konduktif, atau dimana terdapat ketidakteraturan struktur. Pemohonan listrik juga dapat tumbuh karena adanya rongga (void) di dalam material [9].

Kekuatan dielektrik campuran serbuk cangkang kelapa sawit tergantung pada ukuran butiran serbuk cangkang dan persentase bahan campuran. Silicone rubber adalah bahan yang lunak, tetapi jika dicampur dengan serbuk cangkang kelapa sawit diperoleh bahan yang lebih keras. Jadi dengan adanya penambahan serbuk cangkang kelapa sawit diharapkan kekuatan mekanik dari bahan isolasi akan bertambah.

Pada penelitian ini diterapkan metodologi eksperimental. Oleh karena itu percobaan permulaan pemohonan listrik di Laboratorium Tegangan Tinggi Fakultas Teknik UNTAN dengan tegangan pengujian menggunakan tegangan tinggi bolak-balik (AC) dengan frekuensi $50 \mathrm{~Hz}$ menggunakan geometri elektroda jarum elektroda bidang atau elektroda jarum - elektroda jarum. Hal ini merupakan cara yang dapat dilakukan dalam penelitian pemohonan listrik tersebut untuk dijadikan masukan dalam pengembangan dan diversifikasi bahan isolasi [8], [9].

Persiapan awal dari penelitian ini dengan Persiapan Peralatan dan bahan pengujian sebagai berikut :

\section{A. Persiapan sampel dan Pembuatan sampel uji}

Tahap pertama dalam adalah dengan mempersiapkan cangkang kelapa sawit yang sudah kering dan bersih. Kemudian dihaluskan dengan ukuran 80 mesh, serbuk ini ditimbang 0,1 gram yang setara dengan $1 \%$ berat total specimen. Setelah itu serbuk cangkang kelapa sawit di campurkan dengan silicone rubber dengan berat 3,9 gram. Kemudian mempersiapkan elektrodanya yang berbentuk jarum dengan diameter $100 \mu \mathrm{m}$, elektroda tersebut ditajamkan dengan larutan Naoh yang di beri tegangan 5 $\mu \mathrm{m}$. Tahap selanjutnya elektoda tersebut di tempelkan pada slide glass dan ketika sudah kering berikan campuran cangkang kelapa sawit dan silicone rubber biarkan hingga kering seperti Gambar 1. (a).

Tahap kedua sama dengan tahap pertama hanya sampel ujinya dengan menggunakan silicone rubber (tanpa filler) sesuai dengan Gambar 1. (b). Pengeringan dilakukan selama 24 jam dengan suhu ruangan. Bentuk specimen terlihat seperti Gambar 2. berikut ini :

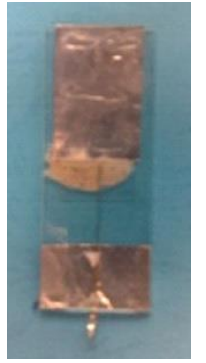

(a)

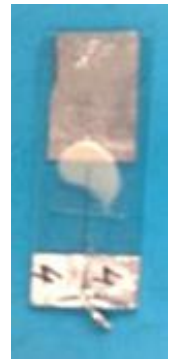

(b)
Gambar 1. Sampel Uji

(a) Filler (Serbuk Cangkang Kelapa Sawit-Silicone Rubber) (b) Tanpa Filler (Silicone Rubber)

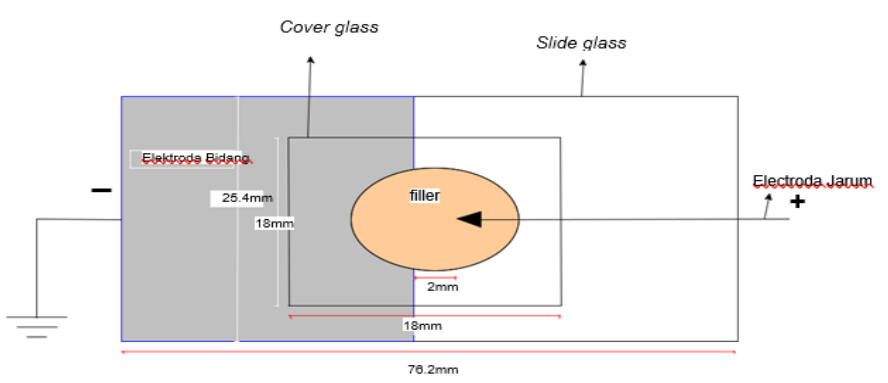

Gambar 2. Bentuk Specimen

\section{B. Teknik Pengamatan Pemohonan Listrik}

Pengamatan ini bertujuan untuk mengamati permulaan pemohonan listrik secara optik pada temperatur ruangan. Pengamatan dibagi dalam beberapa bagian, sebagaimana diuraikan berikut ini :

\section{Pengamatan Tegangan Insepsi}

Tegangan insepsi diamati pada temperatur ruang dengan step tegangan $\mathrm{AC}$, mulai dari $1 \mathrm{kV}$ setiap 5 menit sampai terjadi electrical treeing. Diantara langkahlangkah itu, penerapan tegangan di interupsi untuk beberapa menit lalu sampel diambil dari wadah uji (chamber) berisi minyak silikon dan diamati inisiasi pemohonan listriknya dengan menggunakan mikroskop optik.

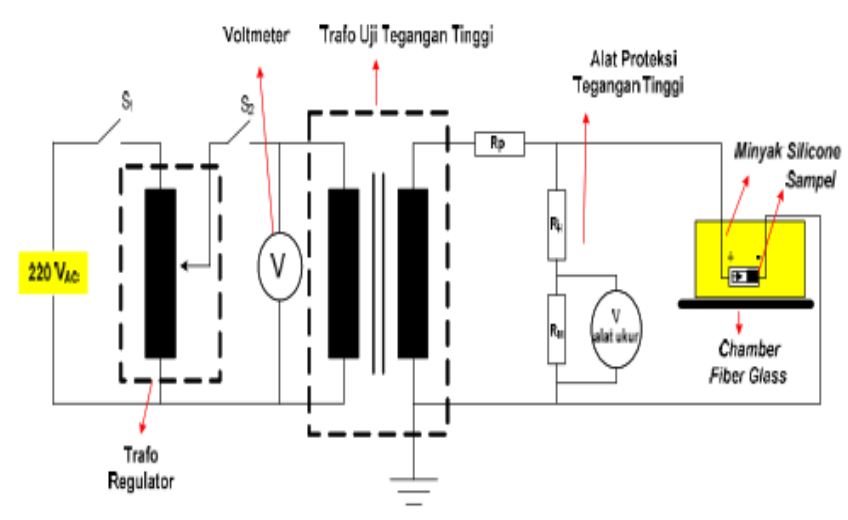

Gambar 3. Rangkaian Percobaan Pemohonan Listrik

\section{Pengamatan Waktu Insepsi}

Percobaan waktu insepsi (inception time) pada sampel dilakukan 3 kali percobaan untuk mendapatkan nilai ratarata waktu insepsinya. Percobaan ini mengacu pada 
percobaan tegangan insepsi, dimana besarnya tegangan insepsi pada sampel menjadi patokan. Apabila tegangan insepsi suatu jenis bahan sampel diketahui sebesar $10 \mathrm{kV}$, maka diterapkan tegangan $9 \mathrm{kV}$ pada jenis bahan sampel dan pada temperatur yang sama selama 30 detik, setelah itu tegangan diinterupsi beberapa detik, sampel diambil dari wadah uji dan diamati dengan mikroskop apakah telah terbentuk pemohonan listrik atau belum, jika telah terbentuk berarti lamanya waktu insepsi untuk tegangan 9 $\mathrm{kV}$ adalah 30 detik, dan jika belum, tegangan $9 \mathrm{kV}$ diterapkan lagi pada sampel itu selama 30 detik, demikian seterusnya hingga terbentuk pemohonan listrik. Lamanya waktu insepsi merupakan penjumlahan beberapa selang waktu 30 detik tersebut. Cara yang sama dilakukan pada tegangan $8 \mathrm{kV}$ dan seterusnya sampai pada tegangan $5 \mathrm{kV}$ dengan step tegangan $1 \mathrm{kV}$. Sedangkan untuk mencari lama waktu insepsi tegangan $9 \mathrm{kV}$ ke atas, dengan step tegangan $1 \mathrm{kV}$ diterapkan tegangan itu untuk setiap interval waktu 30 detik hingga terbentuknya pemohonan listrik, waktu insepsinya berarti jumlah dari setiap interval waktu tersebut hingga terbentuknya pemohonan listrik.

Langkah-langkah dalam penelitian :

- Persiapan bahan dengan membersihkan cangkang kelapa sawit selanjutnya cangkang dicuci lalu dijemur dengan lama waktu 3 jam, setelah kering cangkang dihancurkan dijadikan serbuk dengan ukuran 80 mesh (80 lubang per $\mathrm{cm}^{2}$ ). Serbuk cangkang kelapa sawit dengan ukuran 80 mesh selanjutnya ditimbang sebanyak 0,1 gram yang setara dengan $1 \%$ berat total specimen.

- Elektrodanya adalah sebatang jarum dengan diameter $100 \mu \mathrm{m}$ dengan bagian ujung jarum tersebut ditajamkan dengan larutan $\mathrm{NaOH}$ yang telah diberi tegangan hingga tercapai radius kurvatur $5 \mu \mathrm{m}$.

- Menyediakan sampel uji "filler" yaitu dengan mencampurkan serbuk cangkang kelapa sawit 0,1 gr dan silicone rubber dengan berat 3,9 gram (seperti Gambar 1.a). Dalam pencampuran ini hendaknya hati-hati karena apabila banyak mengandung void maka sampel uji ini cepat mengalami flashover.

- Menyediakan sampel uji "tanpa filler" yaitu hanya silicone rubber saja tanpa dicampur apa-apa (seperti Gambar 1.b).

- Slide glass diberi alumunium foil dan larutan sampel uji dibagian atasnya.

- Elektroda jarum ditempel di atas larutan sampel tersebut dengan lem aron alfa, kemudian ditutup dengan cover glass serta ujung elektrodanya dibungkus dengan alumunium foil.

- Setelah itu dibiarkan sampai kering. Pengeringan dilakukan dengan cara mendiamkan bahan specimen selama 24 jam dalam suhu ruangan.

- Sampel dikatakan sempurna apabila isolasinya tidak banyak mengandung void.

- Lakukan pengujian sesuai dengan prosedur penelitian.

- Amati tegangan dan waktu insepsi pemohonan listrik.

- Analisa hasilnya dan menyimpulkan hasil penelitian tersebut.

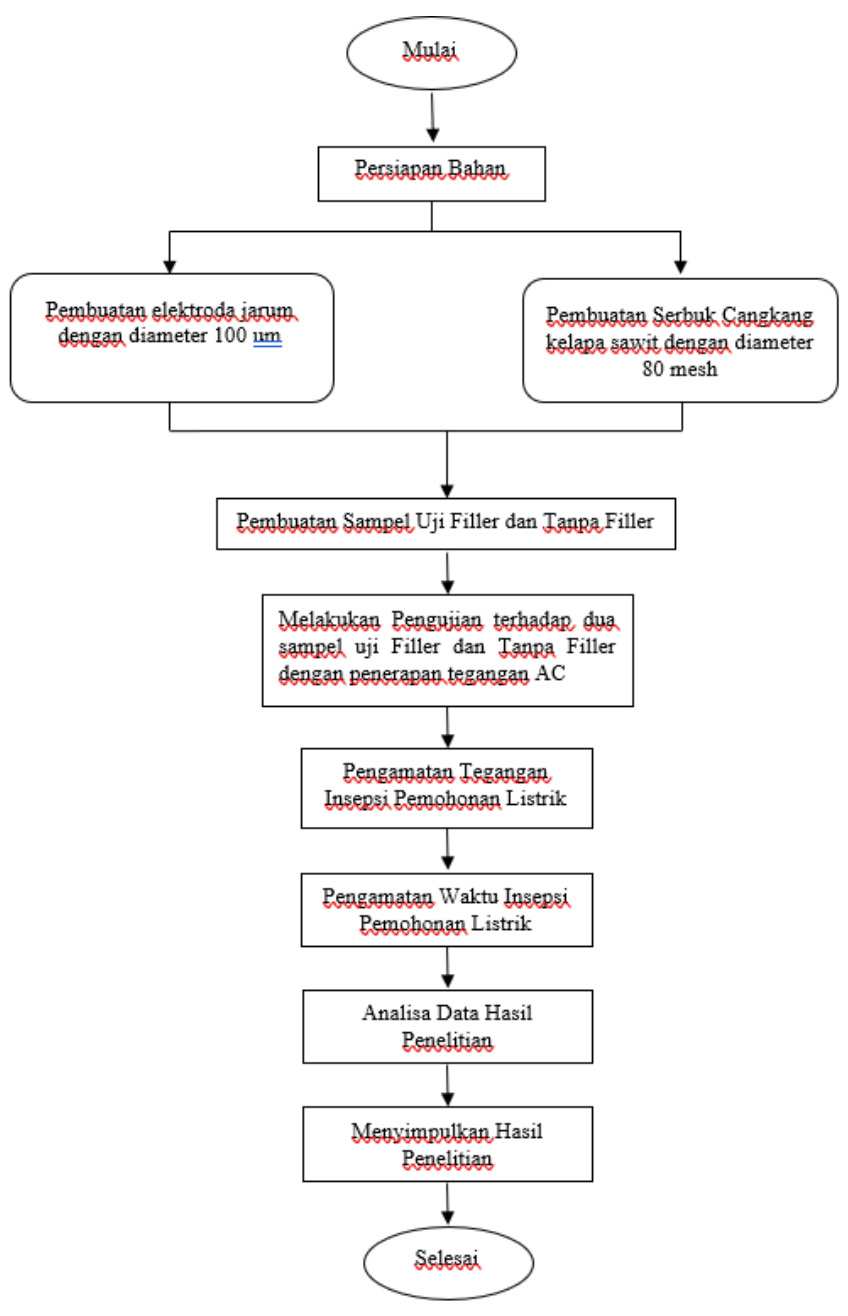

Gambar 4. Diagram Alir Pembuatan Sampel Uji Bahan Komposit Silicone Rubber dan Serbuk Cangkang Kelapa Sawit

\section{Hasil dan Pembahasan}

\section{A. Hasil}

1. Tegangan Insepsi (Inception Voltage)

Studi laboratorium yang dilakukan dengan menggunakan elektroda jarum pada tegangan AC menunjukkan bahwa tegangan insepsi yang terjadi treeing berkisar $5 \mathrm{kV}$ hingga $9 \mathrm{kV}$, dapat dilihat pada tabel hasil pengujian dibawah ini :

Tabel 1. Data Hasil Pengujian Tegangan Insepsi

\begin{tabular}{ccccc}
\hline $\begin{array}{c}\text { Tegangan } \\
\text { yang } \\
\text { diterapkan } \\
\text { (kv) }\end{array}$ & \multicolumn{2}{c}{ Dengan Filler } & \multicolumn{2}{c}{ Tanpa Filler } \\
\cline { 2 - 5 } & $\begin{array}{c}\text { Percobaa } \\
\mathrm{n} 1\end{array}$ & $\begin{array}{c}\text { Percobaa } \\
\mathrm{n} 2\end{array}$ & $\begin{array}{c}\text { Percobaa } \\
\mathrm{n} 1\end{array}$ & $\begin{array}{c}\text { Percobaa } \\
\mathrm{n} 2\end{array}$ \\
\hline 4 & $\sqrt{ }$ & $\sqrt{ }$ & $\sqrt{ }$ & $\sqrt{ }$ \\
\hline 5 & $\sqrt{ }$ & $\sqrt{ }$ & Treeing & $\sqrt{ }$ \\
\hline 6 & $\sqrt{ }$ & $\sqrt{ }$ & $\sqrt{ }$ & $\sqrt{ }$ \\
\hline 7 & $\sqrt{ }$ & $\sqrt{ }$ & $\sqrt{ }$ & $\sqrt{ }$ \\
\hline 8 & treeing & Treeing & Treeing & treeing \\
\hline 9 & $\sqrt{ }$ & $\sqrt{ }$ & Treeing & $\sqrt{ }$ \\
\hline
\end{tabular}


Berdasarkan tabel di atas, perhitungan tegangan insepsi rata-rata adalah penjumlahan dari tegangan pada percobaan 1 dengan tegangan pada percobaan 2 yang terjadi treeing dibagi dengan banyaknya tegangan yang terjadi treeing. Seperti pada Tabel 2 di bawah ini :

Tabel 2. Data Hasil Perhitungan Tegangan Insepsi

\begin{tabular}{ccc}
\hline Waktu yang & \multicolumn{2}{c}{ Tegangan Insepsi rata-rata } \\
\cline { 2 - 3 } ditetapkan & Filler & Tanpa Filler \\
\hline 5 menit & $8 \mathrm{kV}$ & $7,5 \mathrm{kV}$ \\
\hline
\end{tabular}

Gambar 5. dan Gambar 6. merupakan tampilan hasil foto mikroskop tegangan insepsi, dimana tampak jelas telah terjadi pemohonan listrik (treeing) dengan filler dan tanpa filler pada percobaan 1 dan percobaan 2

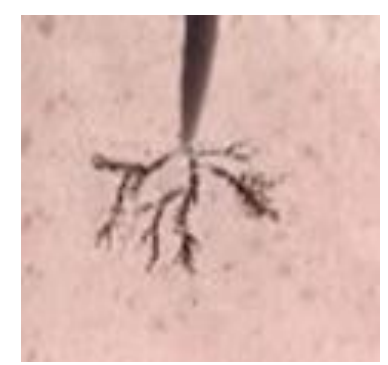

(a)

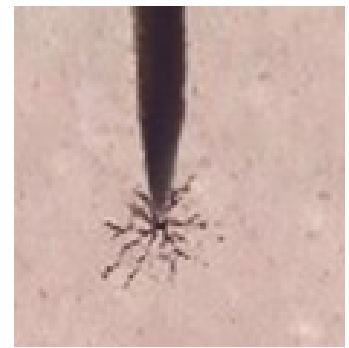

(b)
Gambar 5. Treeing pada Sampel Uji Filler Tegangan $8 \mathrm{kV} / 5$ Menit :

(a) Percobaan 1

(b) Percobaan 2
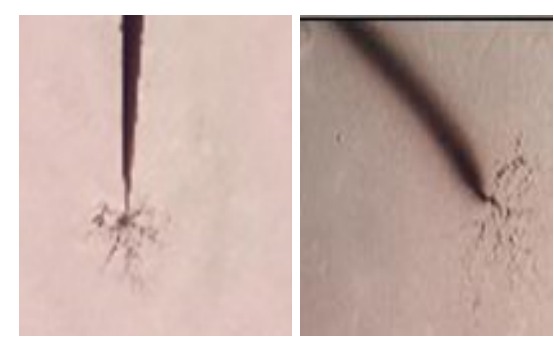

(a)

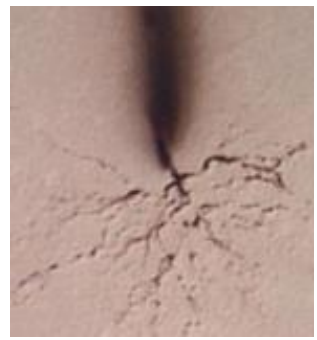

(b)

Gambar 6. Treeing Pada Sampel Uji Tanpa Filler / 5 menit :

(a) Percobaan $1(5 \mathrm{kV}, 8 \mathrm{kV}, 9 \mathrm{kV})$

(b) Percobaan $2(8 \mathrm{kV})$

\section{Waktu Insepsi (Inception Time)}

Studi laboratorium yang dilakukan dengan menggunakan geometri elektroda jarum dan plat pada tegangan $\mathrm{AC}$ menunjukkan bahwa waktu insepsi berkisar antara 137 detik (2,28 menit) sampai 182 detik (3 menit) seperti terlihat pada Tabel 3 dan Tabel 4.

Tabel 3. Data Hasil Pengujian Waktu Insepsi

\begin{tabular}{|c|c|c|c|c|c|c|c|c|c|c|c|c|}
\hline \multirow{4}{*}{$\begin{array}{l}\text { Waktu } \\
\text { (detik) }\end{array}$} & \multicolumn{12}{|c|}{ Tegangan yang diterapkan $(\mathrm{kV})$} \\
\hline & \multicolumn{2}{|c|}{5} & \multicolumn{2}{|c|}{6} & \multicolumn{2}{|c|}{7} & \multicolumn{2}{|c|}{8} & \multicolumn{2}{|r|}{9} & \multicolumn{2}{|c|}{10} \\
\hline & $\mathrm{F}$ & $\mathrm{T}$ & $\mathrm{F}$ & $\mathrm{T}$ & $\mathrm{F}$ & $\mathrm{T}$ & $\mathrm{F}$ & $\mathrm{T}$ & $\mathrm{F}$ & $\mathrm{TF}$ & $\mathrm{F}$ & $\mathrm{T}$ \\
\hline & & $\mathrm{F}$ & & $\mathrm{F}$ & & $\mathrm{F}$ & & $\mathrm{F}$ & & & & $\mathrm{F}$ \\
\hline 30 & $\sqrt{ }$ & $\sqrt{ }$ & $\sqrt{ }$ & $\sqrt{ }$ & $\sqrt{ }$ & $*$ & $\sqrt{ }$ & $\sqrt{ }$ & $\sqrt{ }$ & $*$ & $\sqrt{ }$ & $\sqrt{ }$ \\
\hline 60 & $\sqrt{ }$ & $\sqrt{ }$ & $\sqrt{ }$ & $\sqrt{ }$ & $\sqrt{ }$ & $\sqrt{ }$ & * & $\sqrt{ }$ & $\sqrt{ }$ & $\sqrt{ }$ & $*$ & $*$ \\
\hline 90 & $\sqrt{ }$ & $\sqrt{ }$ & $\sqrt{ }$ & $*$ & $\sqrt{ }$ & - & * & - & & - & - & - \\
\hline 120 & $\sqrt{ }$ & - & $\sqrt{ }$ & - & $\sqrt{ }$ & $\sqrt{ }$ & - & $\sqrt{ }$ & - & $\sqrt{ }$ & - & - \\
\hline 150 & $\sqrt{ }$ & $\sqrt{ }$ & $\sqrt{ }$ & - & $\sqrt{ }$ & $\sqrt{ }$ & - & - & - & - & - & - \\
\hline 180 & - & * & - & - & - & - & - & - & * & $*$ & $*$ & - \\
\hline 120 & $\sqrt{ }$ & $\sqrt{ }$ & $\sqrt{ }$ & $\sqrt{ }$ & $\sqrt{ }$ & $\sqrt{ }$ & $v$ & 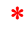 & V & $\sqrt{ }$ & $*$ & * \\
\hline 240 & $*$ & * & $\sqrt{ }$ & $*$ & $\sqrt{ }$ & - & V & 1 & $\sqrt{ }$ & rusak & $\sqrt{ }$ & $\sqrt{ }$ \\
\hline 360 & $*$ & $\sqrt{ }$ & $\sqrt{ }$ & $\sqrt{ }$ & $\sqrt{ }$ & * & * & $v$ & $\sqrt{ }$ & $\sqrt{ }$ & - & - \\
\hline 480 & - & - & - & - & $\sqrt{ }$ & - & - & - & - & - & - & - \\
\hline
\end{tabular}

Keterangan gambar :

$\sqrt{ }=$ ya $($ percobaan 1$) \quad-=\operatorname{tidak}($ percobaan 1$)$

$\sqrt{ }=$ ya $($ percobaan 2$) \quad-$ tidak $($ percobaan 2$)$

* $=$ treeing $($ percobaan 1$) \quad \mathrm{F}=$ Filler

* = treeing (percobaan 2) $\quad \mathrm{TF}=$ Tanpa Filler

- = tidak diterapkan pada sampel karena terjadi flahover dan hasil pengujiannya tidak bagus

Dengan memperhatikan Tabel 3 di atas dapat terlihat bahwa pada tegangan $5 \mathrm{kV}$ sampai $10 \mathrm{kV}$ ada beberapa percobaan gagal yang ditandai dengan tanda (-), hal ini disebabkan karena pada sampel pengujian terjadi flashover. Flashover sendiri adalah gangguan yang terjadi berupa loncatan api yang terjadi antar isolator atau kompenen listrik tegangan tinggi. Hal ini dapat terjadi akibat gagalnya isolasi dari sistem tegangan tinggi tersebut. Kegagalan listrik pada isolator dapat disebabkan oleh adanya rongga-rongga (void) kecil pada sampel uji. Rongga-rongga kecil pada sampel ditimbulkan karena sampel uji dibuat kurang sempurna pada saat pembuatan, dengan demikian karakteristik listrik dari sampel tersebut kurang baik dalam proses pengujian.

Berdasarkan Tabel 3 di atas, perhitungan waktu insepsi rata-rata adalah penjumlahan dari waktu pada percobaan 1 dan percobaan 2 yang terjadi treeing dibagi dengan banyaknya waktu terjadinya treeing. Seperti pada Tabel 4 di bawah ini : 
Tabel 4. Data Hasil Perhitungan Waktu Insepsi Rata-Rata

\begin{tabular}{|c|c|c|}
\hline \multirow[b]{2}{*}{$\begin{array}{l}\text { Tegangan } \\
\text { yang } \\
\text { Diterapkan } \\
(\mathrm{kV})\end{array}$} & \multicolumn{2}{|c|}{ Waktu Insepsi Terjadinya Treeing (detik) } \\
\hline & $\begin{array}{c}\text { Filler (Silicone } \\
\text { Rubber -Serbuk } \\
\text { Cangkang Kelapa } \\
\text { Sawit) }\end{array}$ & $\begin{array}{c}\text { Tanpa Filler } \\
\text { (Silicone Rubber) }\end{array}$ \\
\hline 5 & 300 & 210 \\
\hline 6 & - & 165 \\
\hline 7 & - & 130 \\
\hline 8 & 170 & 120 \\
\hline 9 & 135 & 105 \\
\hline 10 & 120 & 90 \\
\hline Rata-Rata & $182=3$ menit & $137=2,28$ menit \\
\hline
\end{tabular}

Keterangan gambar :

- $\quad$ = tidak terjadi treeing pada percobaan

Gambar 7. dan Gambar 8. merupakan beberapa tampilan gambar hasil percobaan waktu insepsi dengan filler dan tanpa filler, dimana tampak jelas telah terjadi pemohonan listrik (treeing) pada percobaan 1.
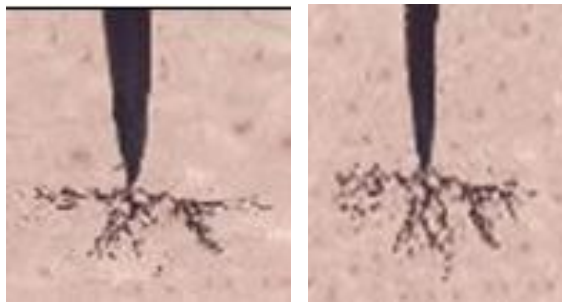

(a)

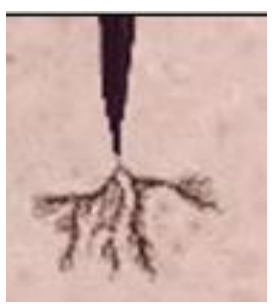

(b)

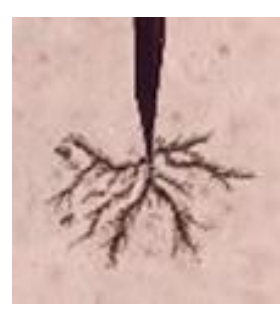

(c)
Gambar 7. Waktu Insepsi Treeing Dengan Filler :

(a) $8 \mathrm{kV} / 60$ detik dan $8 \mathrm{kV} / 90$ detik

(b) $9 \mathrm{kV} / 60$ detik

(c) $10 \mathrm{kV} / 60$ detik

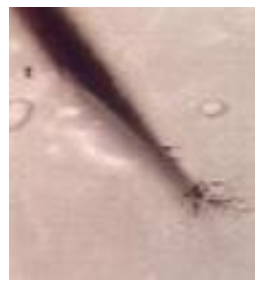

(a)

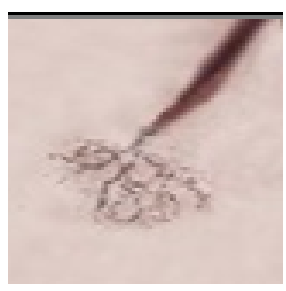

(b)

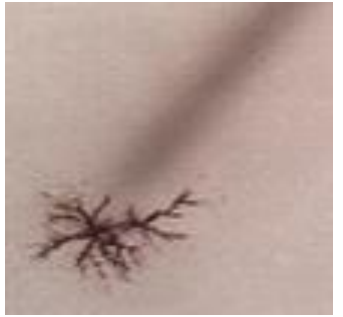

(c)

Gambar 8. Waktu Insepsi Treeing Tanpa Filler :
(a) $7 \mathrm{kV} / 150$ detik
(b) $8 \mathrm{kV} / 120$ detik
(c) $10 \mathrm{kV} / 30$ detik

\section{B. Pembahasan}

1. Tegangan Insepsi (Inception Voltage)

Tegangan insepsi adalah tegangan yang diperlukan pemohonan listrik untuk mulai tumbuh. Tegangan insepsi diamati pada temperatur ruangan tertentu dengan step tegangan $\mathrm{AC}$, mulai dari $1 \mathrm{kV}$ setiap beberapa menit sampai terjadi pemohonan listrik (electrical treeing). Dan tujuan dari perhitungan tegangan insepsi ini adalah untuk mengetahui pada tegangan keberapa pemohonan listrik (electrical treeing) ini mulai terjadi.

Dari Tabel 2. diperoleh grafik hubungan antara tegangan insepsi pemohonan listrik dengan dua sampel yaitu "dengan filler" dan "tanpa filler" pada Gambar 9. seperti di bawah ini :

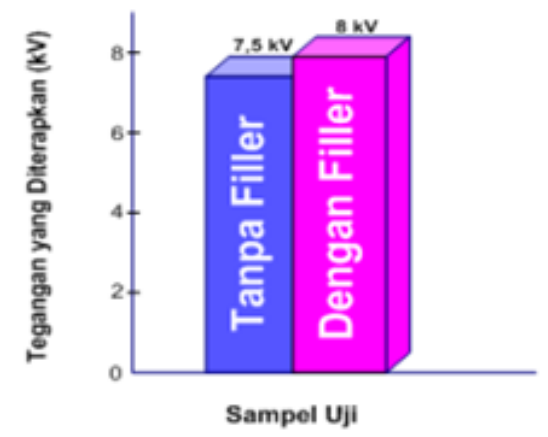

Gambar 9. Grafik Tegangan Insepsi Pemohonan Listrik dengan Dua Sampel Uji

Pada Gambar 9. terlihat bahwa sampel uji "dengan filler" tegangan insepsinya lebih tinggi dibanding dengan sampel uji "tanpa filler". Hal ini disebabkan karena pada sampel uji "dengan filler" terkandung campuran silicone rubber dengan serbuk cangkang kelapa sawit yang dapat menahan atau mengisolasi terjadinya pemohonan listrik (electrical treeing) karena diduga cangkang kelapa sawit berfungsi sebagai penghalang (barrier) pemohonan listrik.

Selain alasan yang telah dikemukakan di atas, masih ada alasan lain yang dapat menjelaskan hasil percobaan pada Gambar 9, yaitu selain berfungsi sebagai penghambat, cangkang kelapa sawit juga berfungsi sebagai penetral. Alasannya akan dijelaskan sebagai berikut : pada siklus positif dan negatif, ketika tegangan 
AC yang diterapkan dinaikkan pada beberapa ribu cycle, maka kuat medan elektrik akan bertambah, electron akan bergerak dipercepat, karenanya sehingga elektron memiliki energi kinetik yang besar pula. Energi kinetik yang dimiliki elektron ini memungkinkan mengionisasi atom gas dalam void bila bertumbukan. Ionisasi menghasilkan elektron berikutnya. Semakin besar kuat medan elektrik yang diterapkan, proses ionisasi semakin cepat sehingga memungkinkan terjadinya banjiran (avalanche) dan peluahan sebagian (partial discharge) yang dapat dihambat oleh serbuk cangkang kelapa sawit. Hal itu disebabkan karena serbuk cangkang kelapa sawit cenderung bermuatan positif yang dapat menetralkan elektron dari elektroda jarum yang bermuatan negatif sehingga tidak terbentuk muatan ruang (homospace), yang mengakibatkan peninggian medan yang memicu terjadinya pemohonan listrik.

\section{Waktu Insepsi (Inception Time)}

Waktu insepsi didefinisikan sebagai waktu yang diperlukan untuk suatu pemohonan listrik menjadi teramati (biasanya panjangnya $10 \mathrm{~m}$ ) ketika tegangan konstan diterapkan. Waktu insepsi ini dapat dihitung dengan menjumlahkan dari setiap interval waktu percobaan hingga terbentuknya pemohonan listrik (electrical treeing). Dan tujuan dari perhitungan waktu insepsi ini adalah untuk mengetahui pada waktu (menit/detik) keberapa pemohonan listrik (electrical treeing) ini terjadi.

Dari Tabel 4 diperoleh grafik hubungan antara waktu insepsi pemohonan listrik dengan tegangan yang diterapkan seperti di bawah ini :

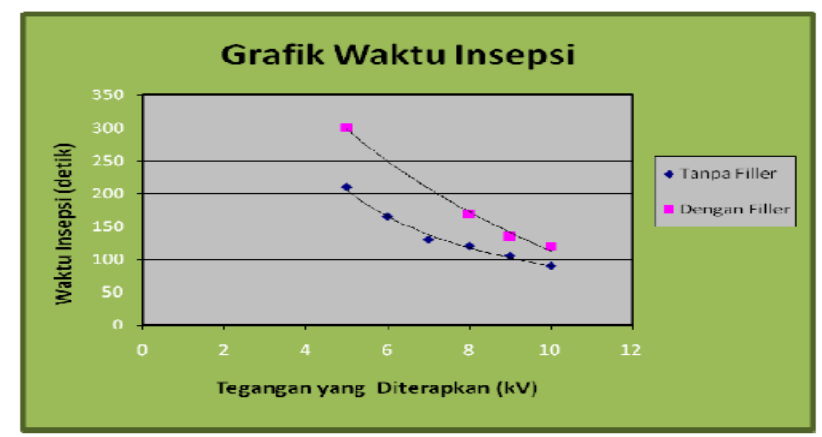

Gambar 10. Grafik Hubungan antara Waktu Insepsi dengan Tegangan yang Diterapkan.

Pada Gambar 10 terlihat bahwa waktu insepsi pada sampel uji "tanpa filler" lebih singkat dibandingkan dengan waktu insepsi pada sampel uji “dengan filler". Hal ini disebabkan karena beberapa faktor yaitu :

- Sifat-sifat fisik bahan dari kedua sampel uji,

- Tegangan yang diterapkan.

Sifat fisik bahan dari sampel uji "dengan filler" (campuran silicone rubber dengan serbuk cangkang kelapa sawit) dan "tanpa filler" (silicone rubber) antara lain :
- $\quad$ Silicone rubber bersifat hidrofobik yaitu mampu menolak air serta sifat dielektriknya sangat baik apabila ditambahkan dengan bahan pengisi yang berfungsi sebagai penguat, pelindung, pelumasan, serta perbaikan sifat pencetakan.

- Sedangkan bahan pengisi cangkang kelapa sawit diduga berfungsi sebagai penghalang (barrier) pemohonan listrik karena kekuatan dielektrik cangkang kelapa sawit dapat menghalangi terjadinya stress medan listrik yang tinggi, sehingga terjadinya waktu insepsi tidak terlalu cepat.

Kekuatan mekanik silicone rubber tanpa bahan pengisi rendah karena gaya antar rantai molekulnya rendah, sehingga memicu terjadinya waktu insepsi yang cepat. Kedua sampel uji dikenai tegangan yang bervariasi, mulai dari $5 \mathrm{kV}$ hingga $10 \mathrm{kV}$, agar terlihat perbedaan waktu insepsinya untuk masing-masing sampel uji. Hasil-hasil percobaan juga menunjukkan bahwa waktu insepsi adalah fungsi tegangan. Semakin tinggi tegangan yang diterapkan, maka akan semakin cepat waktu terbentuknya pemohonan listrik (waktu insepsi), atau dengan kata lain semakin kecil tegangan yang diterapkan, maka proses pembentukan pemohonan listrik akan semakin lama.

Semakin tinggi tegangan yang diterapkan, maka elektron bebas akan mendapatkan energi yang lebih besar untuk menjadi energi kinetik yang akhirnya dapat memutus rantai polimer.

\section{KESIMPULAN}

Berdasarkan hasil pengujian menunjukkan bahwa waktu insepsi adalah fungsi tegangan. Semakin tinggi tegangan yang diterapkan, maka akan semakin cepat waktu terbentuknya permulaan pemohonan listrik, tetapi tidak berlaku pada sampel uji dengan filler. Terlihat dari hasil pengujian tegangan dan waktu insepsi pada sampel uji "dengan filler" sebesar $8 \mathrm{kV} / 182$ detik dan "tanpa filler" sebesar 7,5 kV/137 detik. Hal ini disebabkan karena sampel uji "dengan filler" berfungsi sebagai penghalang (barrier) permulaan pemohonan listrik dan dapat meningkatkan kekuatan dielektrik yang menghalangi stress medan listrik yang tinggi, sehingga terjadinya waktu insepsi tidak terlalu cepat.

Dari penelitian ini juga didapatkan bahwa kenaikan tegangan dapat menaikkan medan di ujung elektroda jarum dan menaikkan medan disekitarnya. Dengan adanya kenaikan tegangan kemungkinan bertambahnya jumlah saluran (kanal-kanal) pemohonan listrik semakin besar sehingga struktur pemohonan listrik yang terjadi akan berbeda-beda bentuknya.

\section{Daftar Pustaka}

[1] R. Kurnianto, Z. Nawawi, H. Ahmad, N. Hozumi, dan M. Nagao, "Effect of nano filler mixture on the visual aspect of treeing degradation in LDPE based composite," Gaodianya Jishu/High Volt. Eng., 2011.

[2] H. Herman, N. Freebody, A. Pye, dan G. C. Stevens, "Investigating dielectrics using chemometric methods," in 
Proceedings of the IEEE International Conference on Properties and Applications of Dielectric Materials, 2018, doi: 10.1109/ICPADM.2018.8401059.

[3] R. Kurnianto, Y. Murakami, N. Hozumi, dan M. Nagao, "Electrical tree propagation in epoxy resin under different characteristics," in Proceedings of the International Symposium on Electrical Insulating Materials, 2005, doi: 10.1109/iseim.2005.193471.

[4] H. V. P. Nguyen dan B. T. Phung, "Void discharge behaviours as a function of cavity size and voltage waveform under very low-frequency excitation," High Volt., 2018, doi: 10.1049/hve.2017.0174.

[5] A. Syakur, Y. Z. Arief, Z. A. Malek, dan H. Ahmad, "An experimental study on partial discharge characteristics of polyvinyl chloride (PVC) under AC - DC voltages," in PECon 2008 - 2008 IEEE 2nd International Power and Energy Conference, 2008, doi: 10.1109 / PECON. 2008.4762750 .

[6] X. Zhang, M. Wang, R. Cheng, K. Wang, J. Gao, dan Q. Zhang, "Study on crystalline morphology and breakdown property of micro-, nano-, micro-/nano-composites," ICEMPE 2017 - 1st Int. Conf. Electr. Mater. Power Equip., hal. 440-443, 2017, doi: 10.1109/ICEMPE.2017.7982123.

[7] B. X. Du, T. Han, dan J. G. Su, "Effects of low temperature on treeing Phenomena of silicone rubber/SiO 2 nanocomposites," in Annual Report - Conference on Electrical Insulation and Dielectric Phenomena, CEIDP, 2013, doi: 10.1109/CEIDP.2013.6748339.

[8] M. F. Pesa Yan Habibillah, "Karakteristik Tegangan Tembus AC pada Material Isolasi Padat Campuran Epoxy Resin dengan Cangkang Kelapa Sawit," Jom FTEKNIK, vol. 4 No.1 Feb, 2017.

[9] H. Zheng, S. M. Rowland, dan N. Jiang, "Influence of electrode separation on electrical treeing in a glassy epoxy resin," in Annual Report - Conference on Electrical Insulation and Dielectric Phenomena, CEIDP, 2018, doi: 10.1109/CEIDP.2017.8257519.

[10] O. L. Vasdazara, H. Ardhyananta, dan S. T. Wicaksono, "Pengaruh Penambahan Serat Cangkang Kelapa Sawit (Palm Kernel Fiber) Terhadap Sifat Mekanik Dan Stabilitas Termal Komposit Epoksi/Serat Cangkang Kelapa Sawit," J. Tek. ITS, 2018, doi: 10.12962/j23373539.v7i1.28200.

[11] N. Yuniarti dan A. N. Afandi, "Tinjauan sifat hidrofobik bahan isolasi silicone rubber," Tekno UM MALANG, 2007. 